\title{
HOTEL LOCATION IN TOURISM CITIES Madrid 1936-1998
}

\author{
Ainhoa Urtasun \\ Universidad Pública de Navarra, Spain \\ Isabel Gutiérrez \\ Universidad Carlos III de Madrid, Spain
}

\begin{abstract}
To determine how the positioning of new hotels is affected by the distribution of similar incumbent competitors, this paper investigates geographic location, price, size, and services. With data on all 240 hotels operating in the city of Madrid between 1936 and 1998 , a model of geographic and product location at the time of the hotels' foundings is estimated based on the above mentioned variables. These are simultaneously determined and contingent upon the changing socioeconomic and urban circumstances of the city. The findings suggest that agglomeration occurs only among differentiated establishments. In the balance between agglomeration and differentiation strategies, particularly significant is the trade-off between price and geographic dimensions. Keywords: hotels, location, Madrid.
\end{abstract}

Résumé: Emplacement des hôtels dans les villes touristiques: Madrid 1936-1998. Pour déterminer comment le positionnement des nouveaux hôtels est affecté par la distribution des concurrents similaires et déjà établis, cet article examine situation géographique, prix, grandeur et services. Avec des données sur tous les 240 hôtels en opération à Madrid entre 1936 et 1998, on calcule un modèle de la situation géographique et des services au moment de la fondation des hôtels, en se basant sur les variables surmentionnées. Celles-ci dépendent au même temps des circonstances urbaines et socioéconomiques changeantes de la ville. Les résultats suggèrent que l'agglomération a lieu seulement parmi les établissements différenciés. Dans l'équilibre entre les stratégies d'agglomération et de différentiation, le compromis entre prix et situation est particulièrement significatif. Mots-clés: hôtels, situation, Madrid.

\section{INTRODUCTION}

Hotel entrepreneurs face important decisions when developing new establishments. This article analyzes choices made about geographic location and product positioning-defined here by price, size, and services-during the entry stage. In this tourism sector, these decisions are critical due to the high cost of relocation and product reconfiguration. In addition, demand is uncertain, and demand and competition are

\footnotetext{
Ainhoa Urtasun is Assistant Professor at the Universidad Pública de Navarra (Departamento de Gestión de Empresas, Campus Arrosadía, 31006 Pamplona, Spain. Email <ainhoa.urtasun@unavarra.es>). Her thesis deals with urban tourism and the survival of Spanish hotel chains. She received her PhD from the Universidad Carlos III de Madrid. Isabel Gutiérrez is Professor at the Universidad Carlos III de Madrid. Her fields of interests include macroorganizational theory and industrial dynamics.
} 
segmented by geography and product type (Baum and Haveman 1997). This paper defines conformity as the extent to which a new hotel's position in geographic and product space conforms to the positions of existing locales. Entrepreneurs must decide if the new property will conform to the position of its competitors or will be differentiated. To be similar to or different from competitors is a decision that creates tension in a firm, as researchers have recognized (Baum and Haveman 1997; Chun and Kalnins 2001, 2004; Deephouse 1999). This article examines the gap between the contradictory predictions inherent in the differentiation and agglomeration approaches utilizing an applied study on hotel location in Madrid.

Using data on all hotel foundings in the city of Madrid from 1936 to 1998, a model of geographic and product location at founding is estimated. This model resembles that developed by Baum and Haveman (1997), which was applied to the Manhattan hotel sector, yet differs from it in three ways. First, this paper adds an additional dimension (services) to the original three dimensions (geographic location, price, and size), in which "size is closely tied to the scope and scale of a hotel's services" (1997:314); this paper differs by introducing an explicit measure for the scope and scale of the property's services. Second, in addition to geographically proximate hotels, all establishments falling in the same price range are compared. Lastly, the model of geographic and product location developed here controls for differences in economies of geography and urbanization among zones in the city. Therefore, the primary purpose of this investigation is to explore urban hotel entrepreneurs' choices regarding geographic location as well as decisions around product characteristics that must be addressed upon entry to the market. The second goal is to glean insights into the integration of the agglomeration and differentiation theories. Finally, the relationship between urban development and the evolution of hotel location is examined.

\section{POSITIONING OF NEW URBAN HOTELS}

Should firms be similar to or different from their competitors? The literature provides a wide range of seemingly conflicting predictions. This paper builds on these contrasting theories and predictions within a framework of economic and organizational models. The goal is to examine the forces that drive decisions about the locations of new hotels.

\section{Conformity}

Based on efficiency explanations, spatial economics models generally predict clustering rather than dispersion of firms with similar market domains. Geographic clustering of competing firms was first modeled by Hotelling (1929). Subsequently, clustering was also supported by extensions of his model to the Lancasterian space of product 
characteristics. Other researchers, however, found that the clustering result was sensitive to the assumptions made by Hotelling (Graitson 1982), in particular to the existence of relocation cost.

Crucial support for Hotelling's clustering result is offered by the concept of agglomeration economies-a term introduced in location theory by Weber $(1909 / 1929)$ to designate positive externalities of mutually adjacent location. In Marshall's (1925) view, agglomeration engenders economies that are external to a firm but internal to a small geographic area, or a "locality". More generally, the "Marshallian externalities" arise as a result of three main causes (Fujita and Thisse 1996): the formation of a highly specialized laborforce based on the accumulation of human capital and face-to-face communication; mass-production, that is, internal returns to scale due to productioncost efficiencies that come from serving a large market (Gordon and McCann 2000); and the availability of specialized input services and modern infrastructure. Quigley (1998) provides a survey of the extensive theoretical literature on the microfoundations of agglomeration economies. Krugman (1991) stresses that agglomeration economies are related to the need for contacts. On the other hand, McCann (1995) points out that sector agglomerations may result from location-biased economies not associated with agglomerations-or economies of geography in Ellinger's (1977) terms-as when firms in the same sector group together because they require the same locationspecific factor or they share suppliers and markets.

There is a large and growing empirical literature, usually focused on cities, that deals with the productivity advantages gained by being located in a center of activity (Åberg 1973; Ciccone and Hall 1996; Henderson 1986, 2003; Moomaw 1981, 1988; Nakamura 1985; Sveikauskas 1975; Tabuchi 1986). In manufacturing industries, according to Henderson, Shalizi and Venables (2001), evidence suggests that agglomeration economies derive mostly from firms conducting similar activities (localization economies) rather than from the scale or diversity of activity outside the local sectors (urbanization economies). Unfortunately, the urban service sector has often been neglected in studies of agglomeration economies (Guimaraes, Figuereido and Woodward 2000). Services have long been regarded as activities induced by the location of industrial activities. But recent studies show that services have their own location strategies, and research on services agglomeration is gaining importance (Tickell 2002). According to Chun and Kalnins (2001, 2004), by agglomerating, service and retail firms minimize consumers' search costs, which in turn heightens demand.

The new institutionalism sociology (DiMaggio and Powell 1983; Meyer and Rowan 1977) provides a distinctive explanation for the tendency of organizations to cluster in product space; it suggests a motivation that challenges the notion of efficiency offered in the literature on spatial economics. Organizations compete not just for resources and consumers but also for political power and institutional legitimacy (Aldrich 1979). "Institutional isomorphism" results from positive externalities that organizations gain by conforming to the values and expectations of the institutional environment. The range of strategic 
conformity in which firms maintain their legitimacy is called the "range of acceptability". A firm that selects strategies outside its range of acceptability is subject to challenges to its legitimacy, reliability, and rationality (Ashforth and Gibbs 1990; Meyer and Rowan 1977).

\section{Differentiation}

A successful firm is one with an attractive differentiated position relative to its competitors, as Porter (1991) notes from a strategic management perspective. A firm's competitive advantages are derived from differentiation from its rivals-either because the company possesses the ability to perform the required activities at a lower cost than rivals can or because it can perform some activities in unique ways that create buyer value allowing it to command a premium price. The resourcebased theory of the firm suggests that similarity in resource requirements among rival companies may increase competition (Barney 1991; Peteraf 1993). Similar entities or organizations that conform to the strategies of others share the same resource requirements. Peteraf (1993) contends that resource heterogeneity is a necessary condition for achieving a competitive advantage; otherwise, rent erosion can occur. Likewise, in organizational ecology, the intensity of competition among entities is predicted to be primarily a function of the similarity in their resource requirements. This argument yields the basic "localized competition" hypothesis: "the more similar a focal organization is to its competitors, the greater the intensity of competition it will experience" (Baum and Mezias 1992:581).

\section{Balance between Conformity and Differentiation}

On the one hand, arguments deriving from spatial economics and new institutional sociology suggest that by locating a new venture close to its competitors, both in geographic and product space, entrepreneurs can obtain positive externalities from their economic and institutional environments. On the other hand, arguments deriving from strategic management, the resource-based view of the firm, and population ecology suggest that by locating a new venture far from its competitors, both in geographic and product space, entrepreneurs can avoid localized competition and achieve competitive advantage.

Because conformity and differentiation both show opportunities and threats for firms, a question arises: by combining these two strategies, does a firm perform better than it would if it pursued each strategy in isolation? Because a firm's position is defined by a multidimensional space of characteristics, a combination of both strategies is possible. In other words, a company can conform to the position of its competitors on some dimensions and differentiate on others. A new business should differ from its competitors on those dimensions in which localized competition would erode its rents and should conform to competitors on those dimensions that offer the potential to deliver agglomerative and legitimacy rewards. Fischer and Harrington 
(1996) demonstrated, in a theoretical model with products requiring visual inspection by consumers, that the more heterogeneous the product the greater the agglomeration.

Hypothesis 1 (Conformity or Differentiation): In positioning a new hotel, entrepreneurs decide either to conform to the positions of competitors or to differentiate from them.

Hypothesis 2 (Balance): In positioning a new hotel, entrepreneurs decide to conform to the positions of competitors on some dimensions and to differentiate on others.

\section{Data Sources}

The data used in this study include information on all 240 hotels operating in the city of Madrid between 1936 and 1998. The main source is the State Official Hotel Guide, published annually since 1936 by Tourspain (Spanish Ministry of Industry, Tourism, and Trade), which covers hotels, hostels, boarding houses, motels, and resorts (the latter four types of accommodations have been excluded from the sample because there is no reliable information about them). From this guidebook, the following data are used: category, year of founding, full name and address of the establishment, advertised daily room rate, number of rooms, and number and type of services offered.

Founding was associated with either construction of a new hotel, conversion of a site from another land use to a hotel, or substantial repositioning of an existing hotel. An existing establishment was defined as having failed if it no longer appeared in the official guide. A one-to-two year disappearance was not considered a failure. Between 1936 and 1998, 195 new hotels were founded in Madrid, and 100 failures occurred. As of 1936, there were 45 hotels in Madrid. Although dates of origin were not available for 14, they were included in the study with randomly assigned dates of origin between 1900 and 1936. Their inclusion does not alter the results. The State Official Hotel Guide is complemented by the State Professional Hotel Guide, published annually by Tourspain, which provides information on all chains operating in Spain since 1986. Software Visualmap 1993-2000 by Visual Gis Engineering provided a means of locating the hotels geographically.

\section{Madrid Urban Development and Hotel Sector Evolution}

At the end of the 19th century, Madrid had a very limited hotel sector. During the 20th century, the increasing number of functions performed by the city in its role as national capital and its improved accessibility resulted in the continuous growth and dynamism of the sector (Gutiérrez 1977). Figure 1 shows five steps of evolution of hotel density between 1900 and 1998 in parallel with the urban development of the city. Figure 1 also presents the number of Madrid chain affiliated hotels since 1986, and the trend is clearly positive. In addition, size, as 


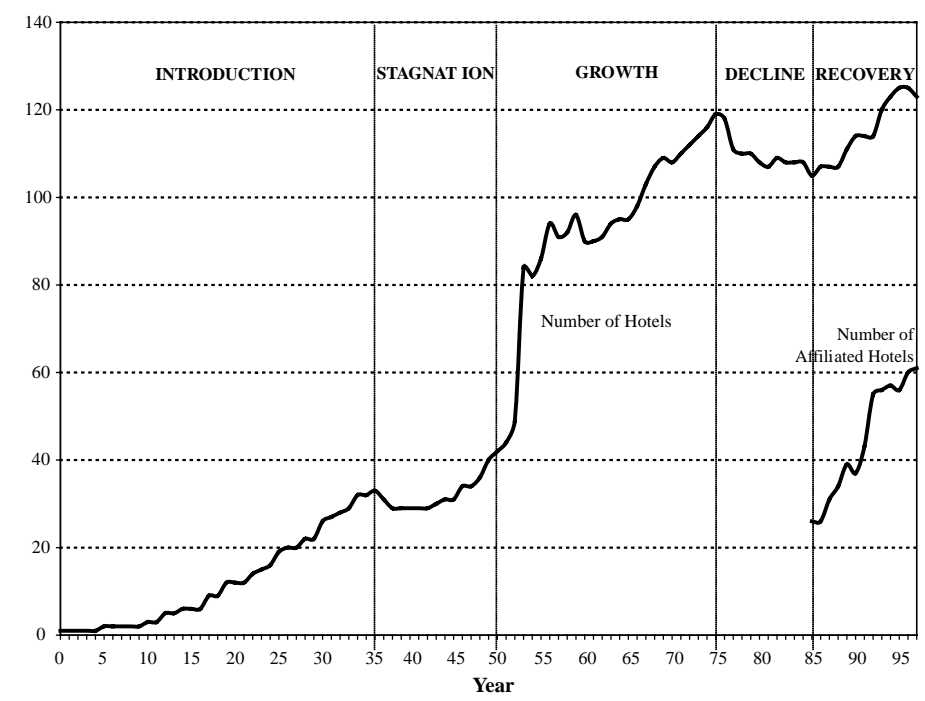

Figure 1. Evolution of Hotel Density and Chain Affiliation (1900-1998)

measured by the average number of rooms per property, doubled from 1953 to 1998, a phenomenon observed in other big cities (Wall, Dudycha and Hutchinson 1985).

The Introduction Phase (1900-1936) shows a slow but continuous growth rate due to the increase in tourist arrival rates after the introduction of the railroad and the construction impetus along the recently completed Gran Vía, an urban artery that crosses the historic city and hosted, up to the 60s, the majority of Madrid's commercial, business, financial, and political activities (Gavira-Martin and GaviraGolpe 1999). Also in this period, the urbanization of the Ensanche, projected in 1860 to develop a new and rational city bordering upon and duplicating the historic city, was concluded. As a result, in 1929, Madrid was organized into three administrative and fiscal zones: Interior, Ensanche, and Outlying, differentiated in both urban structure and living conditions (Ayuntamiento de Madrid 1929). The Stagnation Phase (1936-1950) is a decline phase coincident with the Spanish Civil War and postwar years. Of the hotels that existed in 1936, $13 \%$ failed, and the survivors were left with reduced activity.

The Growth Phase (1950-1975) is characterized by a massive influx of tourists due to the national and North European economic recovery, the economic prosperity of Madrid, and the improvements in transportation infrastructures-developments that led to considerable new construction and defined the current configuration of the sector. The annual rate of new foundings was 4.56. The Decline Phase (19751986) coincides with the worldwide economic crisis. This period registered an annual hotel failure rate of 2.81, higher than the annual 
founding rate of 1.63. Finally, in the Recovery Phase (1986-1998), expansion is stimulated by the reforms undertaken in Madrid's peripheral districts by the new democratic and decentralized politico-administrative entities (Ivars 2004). The annual founding rate rose to 2.91, and the failure rate declined to 1.5.

The spatial distribution of hotels in Madrid today shows three major concentrations: the historic city, the central business district (CBD), and the high-accessibility points. The historic city is the most mature, dense, and heterogeneous zone: economy, mid-price, and luxury hotels are located together, with their current price-spatial distribution resembling the longstanding economic, urban, and social differences of the area. Even today, this part of the city plays a central role in the distribution of services producers: it is the exclusive location for inert activities, such as high-level administration and finance, and the most significant cultural attractions and symbolic spaces of the city are close to it. However, Madrid's historic city area was too constricted to allow proper modern-type CBD functions, prompting new business activities to relocate and creating a new business district. This type of substitution has been observed in other cities, like Xiamen (Bégin 2000) and Brussels (Pillen 1995). In Madrid, since the 40s, a northward vertical development has replaced the initial city core as host to many service-sector activities; this vertical business district is today an area of premium-priced land, and expensive hotels have been selectively attracted to it. Similar hotel patterns in Tel Aviv were identified by Arbel and Pizam (1977), who showed a negative relationship between distance to the CBD and hotel prices. Further, in addition to a high concentration of hotels within the crowded historic district and a desire to move towards more spacious and modern locations, another attraction for new hotels has been high-accessibility points such as train stations and the airport. Similarly, Wall et al (1985) observed in Toronto that hotels tend to concentrate either downtown or in areas close to airports.

\section{Variables}

The data are for newly founded hotels $i=1,2, \ldots, 240$ in their founding year $t(i) \in[1900,1998]$. Thus, the data structure is neither time series nor cross-sectional. Instead, the data represent pooled observations on a variety of new hotels founded sporadically over time.

Endogenous Variables. A four-dimensional vector quantifies the extent to which the positioning of a new hotel conforms to or is differentiated from its competitors. The four components of the vector are distance in geographic location, distance in price, distance in size, and distance in services between the new establishment and its competitors. There are several ways to operationalize firm similarity, an issue particularly debated within the strategic group stream (Hatten and Hatten 1987). First, pairwise data is used in this paper to avoid problems with 
cluster techniques (Barney and Hoskisson 1990). Second, conformity is measured in each of the four components to study how they interact as opposed to aggregating the components into a single measure, as other researchers have done (Deephouse 1999; Gimeno and Woo 1996). Third, two discriminating factors in selecting "true" competitors are considered: the geographic proximity between firms (geographic-competition approach) and their price proximity (pricecompetition approach). Thus, for each new hotel $i$ at its founding time $t(i)$, two different sets of competitors are considered: its 10 nearest geographical neighbors for all existing hotels (geographic-competition approach) and its 10 nearest neighbors in price space for all existing hotels (price-competition approach). This measure assumes that firms focus their attention on narrow sets of organizations competing for similar and scarce resources (Grispud and Gronhaug 1985; Porac and Thomas 1994; Reger and Huff 1993). The analytic expressions of the four outcome variables are the following (with all the variables referring to the focal hotel $i$ 's founding year $t(i))$ :

Geographic distance: $G_{i}=\sum_{j=1}^{10} \sqrt{\left(x_{i}-x_{j}\right)^{2}+\left(y_{i}-y_{j}\right)^{2}} / 10$, where $\left(x_{i}, y_{i}\right)$ are the location coordinates of the new hotel $i$, and $\left(x_{j}, y_{j}\right)$ are the coordinates of one of its competitors.

Price distance: $P_{i}=\sum_{j=1}^{10}\left|p_{i}-p_{j}\right| / 10$, where $p_{i}$ is the price of the new hotel $i$, and $p_{j}$ is the price of one of its competitors (prices in constant monetary units).

Capacity distance: $C_{i}=\sum_{j=1}^{10}\left|r_{i}-r_{j}\right| / 10$, where $r_{i}$ is the number of rooms of the new hotel $i$, and $r_{j}$ is the number of rooms of one of its competitors.

Service distance: $S_{i}=\sum_{j=1}^{10} \sqrt{\sum_{m=1}^{M_{i}}\left(s_{i m}-s_{j m}\right)^{2}} / 10$, with $s_{i m}$ indicating whether the new hotel $i$ offers $\left(s_{i m}=1\right)$ or does not offer $\left(s_{i m}=0\right)$ the service $m, s_{i m}$ referring to one of its competitors, and $M_{i}$ being the total number of different services offered by the established hotels at $t(i)$.

Exogenous Variables. Several deterministic variables affect decisions at founding. Zones $\left(x_{1 i}, x_{2 i}, \ldots, x_{10 i}\right)$ result from splitting the city of Madrid into 10 geographic areas, which are introduced into the model using 9 dummy variables indicating in which area the hotel founding occurred. The purpose is to control for geography and urbanization economies-that is, area-specific benefits other than localization economies-as well as for land use structure. At present, the city of Madrid is divided into 21 districts, structured around a central core and configured into two types of districts, nine interior and 12 exterior. Starting from this current division, districts are grouped or split according to their particular development and evolution. The resultant division resembles that observed by Ashworth (1989a, 1989b) and Ashworth and Tunbridge (1990) in their model of urban hotel location. The 10 clusters are described in Table 1 . Founding $\operatorname{Year}\left(x_{11 i}\right)$ indicates the founding year of the new hotel and controls for temporal circumstances. Category $\left(x_{12 i}\right)$ is a five-level ordinal variable that controls for 
Table 1. Study Zones of Madrid

\begin{tabular}{|c|c|c|c|c|}
\hline Zone & Tag & Current District & Old Division & $\begin{array}{l}\text { Historic and } \\
\text { Current Description }\end{array}$ \\
\hline $\begin{array}{l}\left(x_{1}\right) \text { Historic } \\
\text { Center }\end{array}$ & Historic Madrid & Center & Interior & $\begin{array}{l}\text { Covers all parts ofthe historic } \\
\text { city except the East. }\end{array}$ \\
\hline $\begin{array}{l}\left(x_{2}\right) \text { Gran Vía } \\
\text { Avenue }\end{array}$ & $\begin{array}{l}\text { Commercial \& } \\
\text { CBD }\end{array}$ & Center & Interior & $\begin{array}{l}\text { An urban artery crossing the } \\
\text { historic city from east to west; } \\
\text { the commercial and CBD of } \\
\text { Madrid up to the } 1960 \mathrm{~s} \text {. }\end{array}$ \\
\hline $\begin{array}{l}\left(x_{3}\right) \text { Prado } \\
\text { Avenue }\end{array}$ & Emblematic Zon & Center & Interior & $\begin{array}{l}\text { Covers the aristocratic East } \\
\text { of the historic city, today } \\
\text { one of the city's most symbolic } \\
\text { spaces; an agglomeration } \\
\text { of the city's emblems; } \\
\text { and a financial cluster. }\end{array}$ \\
\hline $\begin{array}{l}\left(x_{4}\right) \text { Castellana } \\
\text { Avenue }\end{array}$ & $\begin{array}{l}\text { Commercial \& } \\
\text { CBD }\end{array}$ & $\begin{array}{l}\text { Salamanca } \\
\text { Chamartín } \\
\text { Chamberí }\end{array}$ & Ensanche & $\begin{array}{l}\text { An urban vertical artery, with } \\
\text { Prado Avenue at its southern } \\
\text { extreme. Since the } 1960 \text { s, } \\
\text { it has replaced Gran Vía as the } \\
\text { commercial and CBD of the city. }\end{array}$ \\
\hline $\begin{array}{l}\left(x_{5}\right) \text { North } \\
\text { East-Ensanche }\end{array}$ & $\begin{array}{l}\text { Intermediate } \\
\text { Zone }\end{array}$ & $\begin{array}{l}\text { Retiro Salamanca } \\
\text { Chamberí }\end{array}$ & Ensanche & $\begin{array}{l}\text { Corresponds to the North and } \\
\text { East parts of the old Ensanche } \\
\text { projected by Castro in } 1886 \text {, } \\
\text { but not configured until the } \\
\text { first third of the 20th century. }\end{array}$ \\
\hline $\begin{array}{l}\left(x_{6}\right) \text { South- } \\
\text { Ensanche }\end{array}$ & $\begin{array}{l}\text { Intermediate } \\
\text { Zone }\end{array}$ & Arganzuela & Ensanche & $\begin{array}{l}\text { Corresponds to the South part of } \\
\text { the old Ensanche. Socially and } \\
\text { economically poorer than the } \\
\text { North-East Ensanche, it was } \\
\text { inhabited by the working classes } \\
\text { until the } 1970 \text { s because of its } \\
\text { proximity to the railroad and } \\
\text { its industrial specialization. }\end{array}$ \\
\hline$\left(x_{7}\right)$ Chamartín & Train Station & Chamartín & Outlying & $\begin{array}{l}\text { Corresponds to the North part of } \\
\text { the old Outlying. It is the newest } \\
\text { interior district, developed } \\
\text { between } 1925 \text { and } 1950 \text {. } \\
\text { This district has an important } \\
\text { train station. }\end{array}$ \\
\hline$\left(x_{8}\right)$ Airport & $\begin{array}{c}\text { International } \\
\text { Airport }\end{array}$ & Hortaleza Barajas & Outlying & $\begin{array}{l}\text { At one time the old North-East } \\
\text { Outlying, with Barajas } \\
\text { international airport, now } \\
\text { houses the biggest convention } \\
\text { and exhibition centers } \\
\text { in Madrid. }\end{array}$ \\
\hline $\begin{array}{l}\left(x_{9}\right) \text { West- } \\
\text { Outskirts }\end{array}$ & Peripheral & $\begin{array}{c}\text { Tetuán Fuencarral } \\
\text { Moncloa }\end{array}$ & Outlying & $\begin{array}{l}\text { Corresponds to the North-West } \\
\text { part of the old Outlying. } \\
\text { Industrial area up to the } \\
1970 \text { s, it was remodeled in the } \\
1980 \text { s under the new political } \\
\text { context. }\end{array}$ \\
\hline $\begin{array}{c}\left(x_{10}\right) \text { South- } \\
\text { Outskirts }\end{array}$ & Peripheral & $\begin{array}{l}\text { Remaining } \\
10 \text { districts }\end{array}$ & Outlying & $\begin{array}{l}\text { Corresponds to the South part } \\
\text { of the Outlying. Remodeled in } \\
\text { the } 1980 \text { s under the new } \\
\text { political context, it currently } \\
\text { contains the cheapest land in } \\
\text { Madrid. }\end{array}$ \\
\hline
\end{tabular}


behaviors at founding vis-a-vis the categories of the World Tourism Organization guidelines. Chain $\left(x_{13 i}\right)$ is a dummy variable that indicates whether the new hotel belongs to a chain at the moment of its founding.

\section{Model Specification}

A system of four simultaneous equations with endogenous explanatory variables is constructed to represent the decisions of hoteliers on the geographic location, price, size, and services supply of their newly founded establishments with respect to existing competitors. Following Baum and Haveman (1997), the four dependent variables, $G, P$, $T$, and $S$ are permitted to affect one another-to be mutually determined. The four-equation Model of Conformity at Founding is specified as follows:

$$
\left\{\begin{array}{l}
G_{i}=\gamma_{P 1} P_{i}+\gamma_{C 1} C_{i}+\gamma_{S 1} S_{i}+X_{1} \beta_{1}+u_{1 i} \\
P_{i}=\gamma_{G 2} G_{i}+\gamma_{C 2} C_{i}+\gamma_{S 2} S_{i}+X_{2} \beta_{2}+u_{2 i} \\
C_{i}=\gamma_{G 3} G_{i}+\gamma_{P 3} P_{i}+\gamma_{S 3} S_{i}+X_{3} \beta_{3}+u_{3 i} \\
S_{i}=\gamma_{G 4} G_{i}+\gamma_{P 4} P_{i}+\gamma_{C 4} C_{i}+X_{4} \beta_{4}+u_{4 i}
\end{array}\right.
$$

Each equation $r$ represents an endogenous variable as a function of the three remaining endogenous variables; a set of $k_{r}$ exogenous variables ( $X_{r}^{\prime}$ 's columns); and an error term $u_{r} \gamma$ estimates location decisions as a consequence of competition costs, legitimacy rewards, and agglomeration economies derived from competing hotels, and $\beta$ estimates location decisions as a consequence of the characteristics of the new hotels and the urbanization economies, economies of geography, and land use structure of the zone where the new hotel is founded. Simultaneity in a system of equations can arise from either (or both) of the following two characteristics: one, the endogenous variables act as explicative variables in the model and two, the error terms of all the equations are contemporaneously correlated. Both possibilities will be checked later. The existence of endogenous explicative variables yields biased and inconsistent ordinary least squares (OLS) estimators of the structural parameters (Koutsoyiannis 1977). A solution to the so-called "simultaneity bias" is to rely on two-stage least squares (2SLS) or three-stage least squares (3SLS) estimation procedures, rather than on OLS. If the random errors are correlated, then 3SLS is more appropriate than 2SLS because it produces more efficient estimates (Zellner and Theil 1962).

\section{Study Results}

Prior to estimating the model in (1), the hotels of the 10 zones are characterized by performing analysis of variance (ANOVA) using data from 1998; Table 2 shows the ANOVA's results. The zones exhibit 
Table 2. ANOVA of Zones (Data of 1998)

\begin{tabular}{|c|c|c|c|c|c|c|c|c|}
\hline Zone & $\begin{array}{c}\text { Founding } \\
\text { Year }\end{array}$ & Category & Price & Capacity & $\begin{array}{l}\text { Services } \\
\quad\left(n^{0}\right)\end{array}$ & $\begin{array}{c}\text { Chain } \\
(\%)\end{array}$ & $\begin{array}{c}\text { Failure } \\
\text { Rate }\end{array}$ & $N$ \\
\hline$\left(x_{1}\right)$ Historic Center & $\begin{array}{l}55.45 \\
(22.06)\end{array}$ & $\begin{array}{l}2.79 \\
(.89)\end{array}$ & $\begin{array}{l}13.26 \\
(5.36)\end{array}$ & $\begin{array}{l}.94 \\
(.55)\end{array}$ & $\begin{array}{l}10.94 \\
(3.37)\end{array}$ & $\begin{array}{l}.15 \\
(.36)\end{array}$ & $\begin{array}{l}.50 \\
(.50)\end{array}$ & 33 \\
\hline$\left(x_{2}\right)$ Gran Vía Avenue & $\begin{array}{l}63.92 \\
(24.14)\end{array}$ & $\begin{array}{l}3.62 \\
(.65)\end{array}$ & $\begin{array}{l}20.70 \\
(7.63)\end{array}$ & $\begin{array}{l}1.68 \\
(.75)\end{array}$ & $\begin{array}{l}15.62 \\
(5.20)\end{array}$ & $\begin{array}{l}.85 \\
(.38)\end{array}$ & $\begin{array}{l}.56 \\
(.50)\end{array}$ & 13 \\
\hline$\left(x_{3}\right)$ Prado Avenue & $\begin{array}{l}50 \\
(37.76)\end{array}$ & $\begin{array}{l}4.00 \\
(1.22)\end{array}$ & $\begin{array}{l}36.48 \\
(25.0)\end{array}$ & $\begin{array}{l}1.79 \\
(1.49)\end{array}$ & $\begin{array}{l}17.80 \\
(5.40)\end{array}$ & $\begin{array}{l}.40 \\
(.55)\end{array}$ & $\begin{array}{l}.57 \\
(.51)\end{array}$ & 5 \\
\hline $\begin{array}{c}\left(x_{4}\right) \text { Castellana } \\
\text { Avenue }\end{array}$ & $\begin{array}{l}68.00 \\
(15.43)\end{array}$ & $\begin{array}{l}4.22 \\
(.44)\end{array}$ & $\begin{array}{l}33.99 \\
(13.6)\end{array}$ & $\begin{array}{l}2.10 \\
(.78)\end{array}$ & $\begin{array}{l}18.78 \\
(5.67)\end{array}$ & $\begin{array}{l}.33 \\
(.50)\end{array}$ & $\begin{array}{l}.25 \\
(.45)\end{array}$ & 9 \\
\hline$\left(x_{5}\right)$ NE-Ensanche & $\begin{array}{l}72.46 \\
(14.63)\end{array}$ & $\begin{array}{l}3.61 \\
(.69)\end{array}$ & $\begin{array}{l}23.12 \\
(6.34)\end{array}$ & $\begin{array}{l}1.70 \\
(1.49)\end{array}$ & $\begin{array}{l}15.25 \\
(4.20)\end{array}$ & $\begin{array}{l}.57 \\
(0.50)\end{array}$ & $\begin{array}{l}.26 \\
(.44)\end{array}$ & 28 \\
\hline$\left(x_{6}\right)$ South-Ensanche & $\begin{array}{l}67.71 \\
(14.29)\end{array}$ & $\begin{array}{l}3.29 \\
(.49)\end{array}$ & $\begin{array}{l}14.70 \\
(3.94)\end{array}$ & $\begin{array}{l}1.59 \\
(1.08)\end{array}$ & $\begin{array}{l}13.14 \\
(3.85)\end{array}$ & $\begin{array}{l}.29 \\
(.49)\end{array}$ & $\begin{array}{l}.13 \\
(.35)\end{array}$ & 7 \\
\hline$\left(x_{7}\right)$ Chamartin & $\begin{array}{l}75.50 \\
(8.14)\end{array}$ & $\begin{array}{l}3.38 \\
(1.06)\end{array}$ & $\begin{array}{l}24.17 \\
(12.0)\end{array}$ & $\begin{array}{l}2.84 \\
(3.00)\end{array}$ & $\begin{array}{l}16.63 \\
(6.39)\end{array}$ & $\begin{array}{l}.75 \\
(.46)\end{array}$ & $\begin{array}{l}.38 \\
(.51)\end{array}$ & 8 \\
\hline$\left(x_{8}\right)$ Airport & $\begin{array}{l}84.17 \\
(12.07)\end{array}$ & $\begin{array}{l}3.58 \\
(.67)\end{array}$ & $\begin{array}{l}19.67 \\
(7.22)\end{array}$ & $\begin{array}{l}1.70 \\
(.73)\end{array}$ & $\begin{array}{l}18.83 \\
(4.90)\end{array}$ & $\begin{array}{l}.75 \\
(.45)\end{array}$ & $\begin{array}{l}.08 \\
(.28)\end{array}$ & 12 \\
\hline$\left(x_{9}\right)$ West-Outskirt & $\begin{array}{l}83.00 \\
(14.09)\end{array}$ & $\begin{array}{l}4.00 \\
(.82)\end{array}$ & $\begin{array}{l}23.58 \\
(1.37)\end{array}$ & $\begin{array}{l}1.08 \\
(.64)\end{array}$ & $\begin{array}{l}14.50 \\
(1.91)\end{array}$ & $\begin{array}{l}.75 \\
(.50)\end{array}$ & $\begin{array}{l}.43 \\
(.53)\end{array}$ & 4 \\
\hline$\left(x_{10}\right)$ South-Outskirt & $\begin{array}{l}84.00 \\
(12.17)\end{array}$ & $\begin{array}{l}3.33 \\
(1.15)\end{array}$ & $\begin{array}{l}12.60 \\
(3.65)\end{array}$ & $\begin{array}{l}1.92 \\
(2.06)\end{array}$ & $\begin{array}{l}12.33 \\
(3.06)\end{array}$ & $\begin{array}{l}.33 \\
(.58)\end{array}$ & $\begin{array}{l}.25 \\
(.50)\end{array}$ & 3 \\
\hline$F$-value ${ }^{\mathrm{e}}$ & - & $4.27^{\mathrm{a}}$ & - & - & $5.37^{\mathrm{a}}$ & - & - & \\
\hline$\chi^{2}$-value ${ }^{e}$ & $28.04^{\mathrm{a}}$ & - & $46.54^{\mathrm{a}}$ & $23.42^{\mathrm{b}}$ & - & $31.17^{\mathrm{a}}$ & $22.80^{\mathrm{b}}$ & \\
\hline Levene $^{\mathrm{e}}$ & $3.58^{\mathrm{a}}$ & 1.13 & $8.16^{\mathrm{a}}$ & $4.08^{\mathrm{a}}$ & 1.35 & $2.92^{\mathrm{a}}$ & $13.89^{\mathrm{a}}$ & \\
\hline
\end{tabular}

${ }^{\mathrm{a}} p<.005 ;{ }^{\mathrm{b}} p<.01 ;{ }^{c} p<.05 ;{ }^{\mathrm{d}} p<.10$; Standard Deviations in parentheses; $N=122$; ${ }^{\mathrm{C}} \mathrm{KRUSKAL} \mathrm{WALLIS} \mathrm{test}$ ( $\chi^{2}$-values) is used to compare mean values when variances between groups are not equal, in other case ANOVA ( $F$-values) is used. Price in monetary units divided by 1,000 ; and capacity in number of rooms divided by 100 .

statistically different means in all the variables: founding year, category, price, size, quantity of services offered, percentage of chain affiliation, and failure rate. The findings are summarized in five points. First, northern and southern zones exhibit significant differences: the most southerly zones show the lowest average category, price, service, and chain affiliation in all Madrid. Second, the zones with the highest mortality rates (around 50\%) are those belonging to the historic city (Prado Avenue $\left(x_{3}\right)$, Historic Center $\left(x_{1}\right)$, and Gran Vía $\left(x_{2}\right)$ ). These zones exhibit the greatest average hotel age (respectively, 48, 42, and 34 years in 1998) and the Historic Center $\left(x_{1}\right)$ and Gran Vía $\left(x_{2}\right)$ have the two highest shares of hotel founding in Madrid: $34.16 \%$ and $20 \%$, respectively. In addition to an age and density effect, such a high mortality rate reflects that, in the $60 \mathrm{~s}$, these zones lost their monopoly position with respect to the commercial, business, and financial activities of the city. 
Third, zones of the historic city present different profiles. Crossing Historic Center $\left(x_{1}\right)$, where low-category dominates, is Gran Vía $\left(x_{2}\right)$ with medium values for category, prices, size, and services and the highest ratio $(85 \%)$ of chain affiliation in all Madrid. The heterogeneity of the historic city is even more accentuated considering that the most expensive hotels in Madrid are located on Prado Avenue $\left(x_{3}\right)$. Fourth, Castellana Avenue $\left(x_{4}\right)$, Prado Avenue $\left(x_{3}\right)$ 's northward prolongation and current CBD, is the zone with the highest average category. Fifth, the zone with the highest number of services is the Airport $\left(x_{8}\right)$, despite showing medium categories and moderate prices. In addition, it is the zone with the lowest average hotel age (13 years old in 1998) and the lowest mortality rate $(8 \%)$.

The estimation of the model of conformity at founding (1) is presented in Table 3 for the geographic-competition approach and in Table 4 for the price-competition approach-the superscript $G$ denotes distances calculated according to the geographic-competition approach, and the superscript $\mathrm{P}$ denotes distances calculated according to the price-competition approach. OLS, 2SLS, and 3SLS estimates are displayed for each equation, (1.1) to (1.4). Both 2SLS and 3SLS procedures substitute each endogenous explicative variable by conducting an auxiliary regression on all the exogenous variables of the model. Because of severe collinearlity problems among instruments and exogenous variables, a backward selection procedure is applied over the exogenous variables until reaching "acceptable" levels of collinearity. After these adjustments, all the estimated equations are free of collinearity problems and identifiable, since each equation has at least one exogenous variable that is not in any of the three remaining equations. The resultant geographic-competition approach has a maximum variance inflation factor of 6.84 , and no condition number exceeds 21.24, a figure considerably lower than the conventional threshold of 30 (Belsley, Kuh and Welsch 1980). For the price-competition approach, the maximum variance inflation factor is 6.45 , and the maximum condition number is 17.7.

OLS estimation matches Hypothesis 1 (Conformity or Differentiation), in both geographic and price-competition approaches, since all the OLS significant estimates for the distance variables are positive. On the other hand, 2SLS and 3SLS estimates match Hypothesis 2 (Balance). This disparity in the results could be attributable to misspecification caused by simultaneity. The possibility of simultaneity because of endogenous variables acting as explicative variables in the model is checked using Hausman's (1978) specification test. The test rejects the null hypothesis of no simultaneity in the four equations of the geographic-competition approach $\left(\chi_{7}^{2}=26.87, \chi_{10}^{2}=13.66, \chi_{7}^{2}=23.74\right.$, $\left.\chi_{7}^{2}=4.19\right)$ and of the price-competition approach $\left(\chi_{8}^{2}=10.62, \chi_{10}^{2}=\right.$ $\left.13.97, \chi_{8}^{2}=9.11, \chi_{8}^{2}=8.25\right)$. These results suggest that using an instrumental variable technique like 2SLS or 3SLS to estimate the model in (1) is more appropriate than using OLS. In addition, the BreuschPagan lagrange multiplier test is used to check whether or not the errors are contemporaneously correlated. The test suggests, both for the geographic-competition approach $\left(\chi_{3}^{2}=603.98\right)$ and for the 
Table 3. Conformity at Founding (1936-1998): Geographic-Competition

\begin{tabular}{|c|c|c|c|c|c|c|c|c|c|c|c|c|}
\hline & \multicolumn{3}{|c|}{ Geographic Distance (1.1) } & \multicolumn{3}{|c|}{ Price Distance (1.2) } & \multicolumn{3}{|c|}{ Capacity Distance (1.3) } & \multicolumn{3}{|c|}{ Service Distance (1.4) } \\
\hline & OLS & 2SLS & 3SLS & OLS & 2SLS & 3SLS & OLS & 2SLS & 3SLS & OLS & 2SLS & 3SLS \\
\hline Constant & $\begin{array}{l}.37^{\mathrm{c}} \\
(.16)\end{array}$ & $\begin{array}{l}-1.12^{\mathrm{d}} \\
(.25)\end{array}$ & $\begin{array}{l}-1.51^{\mathrm{a}} \\
(.49)\end{array}$ & $\begin{array}{l}-.55 \\
(.37)\end{array}$ & $\begin{array}{l}-.95^{c} \\
(.47)\end{array}$ & $\begin{array}{l}-1.18^{\mathrm{a}} \\
(.39)\end{array}$ & $\begin{array}{l}.67^{\mathrm{a}} \\
(-12)\end{array}$ & $\begin{array}{l}.65^{c} \\
(.17)\end{array}$ & $\begin{array}{l}.54^{\mathrm{a}} \\
(.13)\end{array}$ & $\begin{array}{l}-1.15^{\mathrm{a}} \\
(.144)\end{array}$ & $\begin{array}{l}-1.05^{\mathrm{a}} \\
(.24)\end{array}$ & $\begin{array}{l}-.72^{\mathrm{a}} \\
(.23)\end{array}$ \\
\hline $\begin{array}{c}\left(\mathrm{G}^{\mathrm{G}}\right) \mathrm{Geo} \\
\text { Dist }^{\mathrm{G}}\end{array}$ & - & - & - & $\begin{array}{l}.04 \\
(.08)\end{array}$ & $\begin{array}{l}-.12 \\
(.15)\end{array}$ & $\begin{array}{l}-.57^{\mathrm{a}} \\
(.09)\end{array}$ & $\begin{array}{l}.02 \\
(.04)\end{array}$ & $\begin{array}{l}.13^{c} \\
(.06)\end{array}$ & $\begin{array}{l}.30^{\mathrm{a}} \\
(.03)\end{array}$ & $\begin{array}{l}.13^{\mathrm{a}} \\
(.04)\end{array}$ & $\begin{array}{l}.22^{\mathrm{c}} \\
(.09)\end{array}$ & $\begin{array}{l}.30^{\mathrm{a}} \\
(.08)\end{array}$ \\
\hline $\begin{array}{c}\left(\mathrm{P}^{\mathrm{G}}\right) \text { Price } \\
\text { Dist }^{\mathrm{G}}\end{array}$ & $\begin{array}{l}.01 \\
(.04)\end{array}$ & $\begin{array}{l}-.80^{c} \\
(.35)\end{array}$ & $\begin{array}{l}-1.11^{\mathrm{a}} \\
(.24)\end{array}$ & - & - & - & $\begin{array}{l}.01 \\
(.03)\end{array}$ & $\begin{array}{l}.18^{c} \\
(.09)\end{array}$ & $\begin{array}{l}.33^{\mathrm{a}} \\
(.06)\end{array}$ & $\begin{array}{l}.08^{\mathrm{a}} \\
(.02)\end{array}$ & $\begin{array}{l}.11 \\
(.08)\end{array}$ & $\begin{array}{l}.22^{\mathrm{a}} \\
(.07)\end{array}$ \\
\hline $\begin{array}{c}\left(\mathrm{C}^{\mathrm{G}}\right) \text { Capac. } \\
\text { Dist }^{\mathrm{G}}\end{array}$ & $\begin{array}{l}.05 \\
(.09)\end{array}$ & $\begin{array}{l}2.44^{\mathrm{b}} \\
(.89)\end{array}$ & $\begin{array}{l}3.13^{\mathrm{a}} \\
(.54)\end{array}$ & $\begin{array}{l}.04 \\
(.12)\end{array}$ & $\begin{array}{l}.93^{\mathrm{d}} \\
(.54)\end{array}$ & $\begin{array}{l}2.03^{\mathrm{a}} \\
(.39)\end{array}$ & - & - & - & $\begin{array}{l}.23^{\mathrm{a}} \\
(.05)\end{array}$ & $\begin{array}{l}.07 \\
(.27)\end{array}$ & $\begin{array}{l}-.29 \\
(.25)\end{array}$ \\
\hline $\begin{array}{c}\left(\mathrm{S}^{\mathrm{G}}\right) \text { Service } \\
\text { Dist }^{\mathrm{G}}\end{array}$ & $\begin{array}{l}.32^{\mathrm{a}} \\
(.07)\end{array}$ & $\begin{array}{l}1.02^{\mathrm{a}} \\
(.34)\end{array}$ & $\begin{array}{l}1.29^{\mathrm{a}} \\
(.28)\end{array}$ & $\begin{array}{l}.59^{\mathrm{a}} \\
(.11)\end{array}$ & $\begin{array}{l}.73^{\mathrm{a}} \\
(.18)\end{array}$ & $\begin{array}{l}.98^{\mathrm{a}} \\
(.15)\end{array}$ & $\begin{array}{l}.14^{\mathrm{c}} \\
(.05)\end{array}$ & $\begin{array}{l}-.17 \\
(.11)\end{array}$ & $\begin{array}{l}-.39^{\mathrm{a}} \\
(.09)\end{array}$ & - & - & - \\
\hline $\begin{array}{c}\left(x_{1}\right) \text { Historic } \\
\text { Center }\end{array}$ & - & - & - & - & - & - & $\begin{array}{l}-.16 \\
(.13)\end{array}$ & $\begin{array}{l}-.09 \\
(.15)\end{array}$ & $\begin{array}{l}-.04 \\
(.08)\end{array}$ & - & - & - \\
\hline $\begin{array}{l}\left(x_{2}\right) \text { Gran } \\
\text { Vía Av. }\end{array}$ & $\begin{array}{l}-.40^{\mathrm{d}} \\
(.20)\end{array}$ & $\begin{array}{l}-.25 \\
(.47)\end{array}$ & $\begin{array}{l}-.13 \\
(.26)\end{array}$ & $\begin{array}{l}-.05 \\
(.29)\end{array}$ & $\begin{array}{l}.04 \\
(.33)\end{array}$ & $\begin{array}{l}-.05 \\
(.25)\end{array}$ & - & - & - & $\begin{array}{l}-.25^{\mathrm{c}} \\
(.11)\end{array}$ & $\begin{array}{l}-.22^{\mathrm{d}} \\
(.12)\end{array}$ & $\begin{array}{l}-.16^{\mathrm{d}} \\
(.11)\end{array}$ \\
\hline $\begin{array}{l}\left(x_{3}\right) \text { Prado } \\
\text { Avenue }\end{array}$ & - & - & - & $\begin{array}{l}1.86^{\mathrm{a}} \\
(.48)\end{array}$ & $\begin{array}{l}1.32^{\mathrm{c}} \\
(.63)\end{array}$ & $\begin{array}{l}.54^{\mathrm{d}} \\
(.41)\end{array}$ & $\begin{array}{l}.63^{\mathrm{b}} \\
(.24)\end{array}$ & $\begin{array}{l}.30 \\
(.30)\end{array}$ & $\begin{array}{l}.00 \\
(.11)\end{array}$ & - & - & - \\
\hline $\begin{array}{l}\left(x_{4}\right) \text { Castellana } \\
\text { Av. }\end{array}$ & - & - & - & $\begin{array}{l}1.15^{\mathrm{c}} \\
(.52)\end{array}$ & $\begin{array}{l}1.04^{\mathrm{d}} \\
(.58)\end{array}$ & $\begin{array}{l}.41 \\
(.38)\end{array}$ & - & - & - & - & - & - \\
\hline$\left(x_{5}\right)$ NE-Ensanche & - & - & - & $\begin{array}{l}.97^{\mathrm{a}} \\
(.32)\end{array}$ & $\begin{array}{l}.89^{c} \\
(.36)\end{array}$ & $\begin{array}{l}.38^{\mathrm{d}} \\
(.25)\end{array}$ & - & - & - & - & - & - \\
\hline$\left(x_{7}\right)$ Chamartin & - & - & - & - & - & - & $\begin{array}{l}.69^{\mathrm{b}} \\
(.25)\end{array}$ & $\begin{array}{l}.61^{c} \\
(.27)\end{array}$ & $\begin{array}{l}.01 \\
(.14)\end{array}$ & - & - & - \\
\hline$\left(x_{8}\right)$ Airport & - & - & - & - & - & - & - & - & - & $\begin{array}{l}-.08 \\
(.25)\end{array}$ & $\begin{array}{l}-.41 \\
(.38)\end{array}$ & $\begin{array}{l}-.32^{\mathrm{d}} \\
(.11)\end{array}$ \\
\hline$\left(x_{9}\right)$ W-Outskirts & $\begin{array}{l}1.54^{\mathrm{a}} \\
(.49)\end{array}$ & $\begin{array}{l}-.57 \\
(1.14)\end{array}$ & $\begin{array}{l}.03 \\
(.38)\end{array}$ & - & - & - & - & - & - & - & - & - \\
\hline$\left(x_{10}\right)$ S-Outskirts & $\begin{array}{l}2.34^{\mathrm{a}} \\
(.63)\end{array}$ & $\begin{array}{l}-.77 \\
(1.82)\end{array}$ & $\begin{array}{l}-.05 \\
(.67)\end{array}$ & - & - & - & - & - & - & - & - & - \\
\hline$\left(x_{11}\right)$ Founding & - & - & - & - & - & - & - & - & - & $\begin{array}{l}.038^{\mathrm{a}} \\
(.00)\end{array}$ & $\begin{array}{l}.03^{\mathrm{a}} \\
(.00)\end{array}$ & $\begin{array}{l}.03^{\mathrm{a}} \\
(.00)\end{array}$ \\
\hline$\left(x_{12}\right)$ Category & - & - & - & $\begin{array}{l}.42^{\mathrm{a}} \\
(.11)\end{array}$ & $\begin{array}{l}.29^{c} \\
(.14)\end{array}$ & $\begin{array}{l}.12^{\mathrm{d}} \\
(.09)\end{array}$ & - & - & - & - & - & - \\
\hline$\left(x_{13}\right)$ Chain & - & - & - & $\begin{array}{l}.73^{\mathrm{d}} \\
(.40)\end{array}$ & $\begin{array}{l}.30 \\
(.51)\end{array}$ & $\begin{array}{l}.14 \\
(.31)\end{array}$ & - & - & - & - & - & - \\
\hline F & $12.4^{\mathrm{a}}$ & $3.8^{\mathrm{a}}$ & $14.8^{\mathrm{a}}$ & $17.3^{\mathrm{a}}$ & $13.2^{\mathrm{a}}$ & $14.8^{\mathrm{a}}$ & $7.0^{\mathrm{a}}$ & $5.4^{\mathrm{a}}$ & $14.8^{\mathrm{a}}$ & $90.5^{\mathrm{a}}$ & $80.1^{\mathrm{a}}$ & $14.8^{\mathrm{a}}$ \\
\hline
\end{tabular}

${ }^{\mathrm{a}} p<.005 ;{ }^{\mathrm{b}} p<.01 ;{ }^{\mathrm{c}} p<.05 ;{ }^{\mathrm{d}} p<.10$; Standard Deviations of estimated coefficients in parentheses; $N=240$.

price-competition approach $\left(\chi_{3}^{2}=226.92\right)$, that a full-information method (3SLS) provides more efficient estimates than a limited-information method (2SLS). Consequently, 3SLS is used to interpret the results.

The 3SLS technique applied to estimate the Model of Conformity at Founding (1) for the geographic-competition approach (Table 3) obtains 11 significant coefficients for the 12 distance variables, of which three are negative; two of these three correspond to the geographic and price relationship. Price distance and geographic distance have a significant negative influence, in both directions, demonstrating that 
Table 4. Conformity at Founding (1936-1998): Price-Competition Approach

\begin{tabular}{|c|c|c|c|c|c|c|c|c|c|c|c|c|}
\hline \multirow[t]{2}{*}{ Zone } & \multicolumn{3}{|c|}{ Geographic Distance (1.1) } & \multicolumn{3}{|c|}{ Price Distance (1.2) } & \multicolumn{3}{|c|}{ Capacity Distance (1.3) } & \multicolumn{3}{|c|}{ Service Distance (1.4) } \\
\hline & OLS & 2SLS & 3SLS & OLS & 2SLS & 3SLS & OLS & 2SLS & 3SLS & OLS & 2SLS & 3SLS \\
\hline Constant & $\begin{array}{l}1.30^{\mathrm{a}} \\
(.20)\end{array}$ & $\begin{array}{l}.64 \\
(.43)\end{array}$ & $\begin{array}{l}.74^{c} \\
(.39)\end{array}$ & $\begin{array}{l}-.54^{c} \\
(.22)\end{array}$ & $\begin{array}{l}-.41 \\
(.25)\end{array}$ & $\begin{array}{l}-.40^{c} \\
(.24)\end{array}$ & $\begin{array}{l}.03 \\
(.19)\end{array}$ & $\begin{array}{l}.17 \\
(.22)\end{array}$ & $\begin{array}{l}.17 \\
(.21)\end{array}$ & $\begin{array}{l}-.84^{\mathrm{a}} \\
(.13)\end{array}$ & $\begin{array}{l}-.90^{\mathrm{a}} \\
(.18)\end{array}$ & $\begin{array}{l}-.77^{\mathrm{a}} \\
(12)\end{array}$ \\
\hline$\left(G^{P}\right)$ Geo. Dist ${ }^{P}$ & - & - & - & $\begin{array}{l}-.02 \\
(.04)\end{array}$ & $\begin{array}{l}.02 \\
(.06)\end{array}$ & $\begin{array}{l}.01 \\
(.06)\end{array}$ & $\begin{array}{l}-.01 \\
(.03)\end{array}$ & $\begin{array}{l}.01 \\
(.04)\end{array}$ & $\begin{array}{l}.04 \\
(.04)\end{array}$ & $\begin{array}{l}.15^{\mathrm{a}} \\
(.03)\end{array}$ & $\begin{array}{l}.09 \\
(.06)\end{array}$ & $\begin{array}{l}.12^{c} \\
(.06)\end{array}$ \\
\hline$\left(\mathrm{P}^{\mathrm{P}}\right)$ Price Dist $\mathrm{P}^{\mathrm{P}}$ & $\begin{array}{l}-.05 \\
(.06)\end{array}$ & $\begin{array}{l}-.38 \\
(.30)\end{array}$ & $\begin{array}{l}-.40^{\mathrm{d}} \\
(.29)\end{array}$ & - & - & - & $\begin{array}{l}.15^{\mathrm{a}} \\
(.04)\end{array}$ & $\begin{array}{l}.20 \\
(.17)\end{array}$ & $\begin{array}{l}.21 \\
(.16)\end{array}$ & $\begin{array}{l}.03 \\
(.03)\end{array}$ & $\begin{array}{l}.24 \\
(.16)\end{array}$ & $\begin{array}{l}.35^{c} \\
(.16)\end{array}$ \\
\hline$\left(\mathrm{C}^{\mathrm{P}}\right)$ Capac. Dist ${ }^{\mathrm{P}}$ & $\begin{array}{l}.03 \\
(.09)\end{array}$ & $\begin{array}{l}.71 \\
(.45)\end{array}$ & $\begin{array}{l}.67^{\mathrm{d}} \\
(.44)\end{array}$ & $\begin{array}{l}.30^{\mathrm{a}} \\
(.08)\end{array}$ & $\begin{array}{l}.83^{\mathrm{c}} \\
(.38)\end{array}$ & $\begin{array}{l}.72^{c} \\
(.35)\end{array}$ & - & - & - & $\begin{array}{l}.23^{\mathrm{a}} \\
(.05)\end{array}$ & $\begin{array}{l}.05 \\
(.27)\end{array}$ & $\begin{array}{l}-.21 \\
(.26)\end{array}$ \\
\hline$\left(\mathrm{S}^{\mathrm{P}}\right)$ Service Dist $\mathrm{P}^{\mathrm{P}}$ & $\begin{array}{l}.61^{\mathrm{a}} \\
(.07)\end{array}$ & $\begin{array}{l}.70^{\mathrm{a}} \\
(.13)\end{array}$ & $\begin{array}{l}.71^{\mathrm{a}} \\
(.13)\end{array}$ & $\begin{array}{l}-.12 \\
(.08)\end{array}$ & $\begin{array}{l}-.39^{c} \\
(.16)\end{array}$ & $\begin{array}{l}-.36^{c} \\
(.16)\end{array}$ & $\begin{array}{l}.17^{\mathrm{a}} \\
(.05)\end{array}$ & $\begin{array}{l}.03 \\
(.09)\end{array}$ & $\begin{array}{l}-.03 \\
(.08)\end{array}$ & - & - & - \\
\hline$\left(x_{1}\right)$ Historic Center & $\begin{array}{l}-.94^{\mathrm{a}} \\
(.18)\end{array}$ & $\begin{array}{l}-.70^{c} \\
(.28)\end{array}$ & $\begin{array}{l}-.80^{\mathrm{a}} \\
(.25)\end{array}$ & - & - & - & $\begin{array}{l}-.00 \\
(.12)\end{array}$ & $\begin{array}{l}-.04 \\
(.12)\end{array}$ & $\begin{array}{l}-.02 \\
(.12)\end{array}$ & - & - & - \\
\hline$\left(x_{2}\right)$ Gran Vía Av. & $\begin{array}{l}-.71^{\mathrm{a}} \\
(.21)\end{array}$ & $\begin{array}{l}-.52^{\mathrm{d}} \\
(.29)\end{array}$ & $\begin{array}{l}-.58^{c} \\
(.26)\end{array}$ & $\begin{array}{l}-.13 \\
(.17)\end{array}$ & $\begin{array}{l}-.16 \\
(.19)\end{array}$ & $\begin{array}{l}-.14 \\
(.18)\end{array}$ & - & - & - & $\begin{array}{l}-.23^{\mathrm{c}} \\
(.10)\end{array}$ & $\begin{array}{l}-.22^{\mathrm{d}} \\
(.11)\end{array}$ & $\begin{array}{l}-.19^{c} \\
(.11)\end{array}$ \\
\hline$\left(x_{g}\right)$ Prado Avenue & - & - & - & $\begin{array}{l}.32 \\
(.29)\end{array}$ & $\begin{array}{l}-.06 \\
(.40)\end{array}$ & $\begin{array}{l}.29 \\
(.37)\end{array}$ & $\begin{array}{l}.69^{\mathrm{a}} \\
(.21)\end{array}$ & $\begin{array}{l}.60^{\mathrm{b}} \\
(.23)\end{array}$ & $\begin{array}{l}.34^{\mathrm{d}} \\
(.21)\end{array}$ & - & - & - \\
\hline$\left(x_{4}\right)$ Castellana Av. & - & - & - & $\begin{array}{l}.65^{c} \\
(.31)\end{array}$ & $\begin{array}{l}.70^{c} \\
(.34)\end{array}$ & $\begin{array}{l}.67^{c} \\
(.30)\end{array}$ & - & - & - & - & - & - \\
\hline$\left(x_{5}\right)$ NE-Ensanche & - & - & - & $\begin{array}{l}.40^{c} \\
(.19)\end{array}$ & $\begin{array}{l}.53^{c} \\
(.22)\end{array}$ & $\begin{array}{l}.56^{\mathrm{a}} \\
(.20)\end{array}$ & - & - & - & - & - & - \\
\hline$\left(x_{7}\right)$ Chamartin & - & - & - & - & - & - & $\begin{array}{l}.59^{\mathrm{b}} \\
(.22)\end{array}$ & $\begin{array}{l}.61^{c} \\
(.24)\end{array}$ & $\begin{array}{l}.86^{\mathrm{a}} \\
(.22)\end{array}$ & $\begin{array}{l}-.12 \\
(.19)\end{array}$ & $\begin{array}{l}.01 \\
(.25)\end{array}$ & $\begin{array}{l}.33^{\mathrm{d}} \\
(.23)\end{array}$ \\
\hline$\left(x_{8}\right)$ Airport & $\begin{array}{l}4.76^{\mathrm{a}} \\
(.32)\end{array}$ & $\begin{array}{l}4.63^{\mathrm{a}} \\
(.39)\end{array}$ & $\begin{array}{l}4.47^{\mathrm{a}} \\
(.38)\end{array}$ & - & - & - & - & - & - & $\begin{array}{l}-.35 \\
(.25)\end{array}$ & $\begin{array}{l}-.01 \\
(.37)\end{array}$ & $\begin{array}{l}-.08 \\
(.36)\end{array}$ \\
\hline$\left(x_{9}\right)$ W-Outskirts & $\begin{array}{l}2.56^{\mathrm{a}} \\
(.42)\end{array}$ & $\begin{array}{l}2.59^{\mathrm{a}} \\
(.50)\end{array}$ & $\begin{array}{l}2.34^{\mathrm{a}} \\
(.42)\end{array}$ & - & - & - & - & - & - & - & - & - \\
\hline$\left(x_{10}\right)$ S-Outskirts & $\begin{array}{l}2.62^{\mathrm{a}} \\
(.55)\end{array}$ & $\begin{array}{l}2.24^{\mathrm{a}} \\
(.69)\end{array}$ & $\begin{array}{l}2.60^{\mathrm{a}} \\
(.60)\end{array}$ & - & - & - & - & - & - & - & - & - \\
\hline$\left(x_{11}\right)$ Founding & - & - & - & - & - & - & - & - & - & $\begin{array}{l}.03^{\mathrm{a}} \\
(.00)\end{array}$ & $\begin{array}{l}.03^{\mathrm{a}} \\
(.00)\end{array}$ & $\begin{array}{l}.03^{\mathrm{a}} \\
(.00)\end{array}$ \\
\hline$\left(x_{12}\right)$ Category & - & - & - & $\begin{array}{l}.32^{\mathrm{a}} \\
(.07)\end{array}$ & $\begin{array}{l}.20^{\mathrm{d}} \\
(.12)\end{array}$ & $\begin{array}{l}.22^{c} \\
(.11)\end{array}$ & $\begin{array}{l}.14^{\mathrm{b}} \\
(.05)\end{array}$ & $\begin{array}{l}.14 \\
(.09)\end{array}$ & $\begin{array}{l}.15^{c} \\
(.08)\end{array}$ & - & - & - \\
\hline$\left(x_{13}\right)$ Chain & - & - & - & $\begin{array}{l}.12 \\
(.24)\end{array}$ & $\begin{array}{l}.33 \\
(.30)\end{array}$ & $\begin{array}{l}.45^{c} \\
(.25)\end{array}$ & - & - & - & - & - & - \\
\hline $\mathrm{F}$ & $85.1^{\mathrm{a}}$ & $63.0^{\mathrm{a}}$ & $59.0^{\mathrm{a}}$ & $8.5^{\mathrm{a}}$ & $7.17^{\mathrm{a}}$ & $59.0^{\mathrm{a}}$ & $11.5^{\mathrm{a}}$ & $8.4^{\mathrm{a}}$ & $59.0^{\mathrm{a}}$ & $70.9^{\mathrm{a}}$ & $56.5^{\mathrm{a}}$ & $59.0^{\mathrm{a}}$ \\
\hline
\end{tabular}

${ }^{\mathrm{a}} p<.005 ;{ }^{\mathrm{b}} p<.01 ;{ }^{\mathrm{c}} p<.05 ;{ }^{\mathrm{d}} p<.10$; Standard Deviations of estimated coefficients in parentheses; $N=240$.

price-localized competition encourages founders of Madrid hotels to avoid geographic concentration and that geographic concentration encourages them to differentiate on price. In other words, founders of new Madrid hotels avoid competing in geographic and price space simultaneously. 3SLS detects a second trade-off with service distance in determining size distance, meaning that service-localized competition prompts founders to differentiate in size from geographic competitors. However, the effect of size distance on service distance is not significant.

SLS estimation applied to the Model of Conformity at Founding (1) for the price-competition approach (Table 4) obtains fewer significant 
coefficients in the distance variables than does its geographic counterpart (only seven against 11). As with the geographic-competition approach, price distance has a significant negative influence on geographic distance. This result corroborates that price competition fosters geographic dispersion of new entries in the Madrid market. However, in this case, the inverse relationship is not significant, nor is the previously observed negative effect of service distance on size distance significant. A different result is also observed in the effect of service distance on price distance, in that the price-competition approach shows a negative association. However, the inverse relationship, that is, the effect of price distance on service distance, is positive. The remaining four significant coefficients for the endogenous variables are positive.

Interestingly, the price-competition approach obtains lower significance on the endogenous variables but higher significance on the exogenous variables than the geographic-competition approach. This suggests that the geographic-competition approach reflects better than the price-competition approach the impacts of agglomeration economies, legitimacy rewards, and competition costs derived from competing hotels, on the positioning of new hotels in Madrid. In contrast, the impacts of area-specific characteristics other than localization economies are better reflected by the price-competition approach.

\section{CONCLUSION}

This study examines four decisions of urban hotel founders-the geographic location, price, size, and services of their new venturesby empirically testing a simultaneous equations model, in which the four dimensions are mutually determined and exogenously affected by a spatial division of Madrid from both historical and contemporary perspectives. The city of Madrid is divided into 10 zones by grouping or splitting the existing districts according to their particular urban development and socioeconomic conditions. ANOVA analysis of the characteristics of hotels by zones gives preliminary results suggesting that the hotel spatial distribution depends on a range of socioeconomic and planning factors operating in an historical context. Previous studies have already described how hotel location and distribution evolve with urban development in other cities (such as Wall et al 1985, in Toronto; Broadway 1993, in Montreal; Burtenshaw, Bateman and Ashworth 1981, in Western European cities; and Pillen 1995, in Brussels). Along the same line, other researchers apply Ashworth and Tunbridge's model of urban hotel location: Weaver (1993) in the Caribbean; de Bres (1994) in small-town Kansas; Timothy and Wall (1995) in Yogyharta; Oppermann, Dim and Amri (1996) in Kuala Lumpur; Bégin (2000) in Xiamen; and Shoval and Cohen-Hattab (2001) in Jerusalem.

One distinctive aspect of Madrid is the longstanding existence of economy hotels in the city center, which contrasts with the traditional view that budget hotels can only be provided at edge-of-city locations: "City centre locations are off-limits due to the price of land, therefore 
budget hotels are forced into out-of-town secondary urban locations on main trunk roads" (Johnson and Clifton 1996:66). Yokeno (1968) also asserted that the relation between land profitability and its costs must determine location. In contrast, Egan and Nield (2000) consider the existence of city-center budget hotels in their urban hotel hierarchical model. Indeed, city-center budget hotels are the segment with the highest growth potential in major British cities where, in recent years, the availability of disused and obsolete office blocks and the existence of various subsidies and of a favorable planning regime have encouraged the conversion of existing building stock into hotels of this type.

Estimation of the model of location at founding shows that there is a complex scheme of interactions among the four decisions: the geographic location, price, size, and services. Beginning with the geographic location decision of the entrepreneur, both estimations (for the geographic- and price-competition approaches) conclude that geographic distance to competitors is reduced by size and services conformity but augmented by price conformity. These results suggest that Madrid founders predicted greater benefits than costs by geographically agglomerating with competitors of similar size and services, but they predicted greater costs than benefits for geographic competition with similarly priced hotels. For the pricing decision, the geographiccompetition approach yields similar conclusions; however, the pricecompetition approach estimates a different scheme, in which geographic clustering is nonsignificant and services conformity is significant and negative. For the sizing decision, the geographiccompetition approach concludes that size conformity is augmented by geographic proximity and price conformity but reduced by service conformity. However, sizing decisions are not endogenously determined according to the price-competition approach. Finally, for the services decision, both approaches conclude that conformity in services increases with geographic proximity and price conformity.

A comparison of the findings of the geographic-competition approach and those of the price-competition approach suggests that a new hotel decides what its nearest geographic competitors will look like mostly according to the predicted localization economies, sector's legitimacy rewards, and competition costs. In contrast, a new business will decide what its most similar price competitors will look like mostly according to the socioeconomic and urban circumstances of the area in which the establishment is being founded.

The model estimates show both consistencies and inconsistencies with previous research. First, the finding of attraction of new properties to markets with hotels of different prices is inconsistent with the results of Baum and Haveman (1997), but consistent with those of Chun and Kalnins (2004), who find that economy and unbranded hotels locate in areas with high counts of upscale operations. Those authors explain that new hotels locate near incumbents with resources that can spill over and avoid locations where incumbents will exploit spillovers without contributing. In contrast to their results that include the possibility of area-specific benefits, this paper controls for area-specific benefits other than localization economies. Second, the result that new hotels 
decide to locate near similarly sized establishments is inconsistent with both Baum and Haveman (1997) and Chun and Kalnins (2001), who find that small hotels benefit from locating near large hotels and that large hotels fare worse when amidst similarly sized establishments. Despite these differences, this paper's findings support the balance hypothesis, as do Baum and Haveman (1997) and Chun and Kalnins (2001, 2004) in the hotel sector and Deephouse (1999) in the banking sector. By conforming, firms obtain positive externalities and, by differentiating, they avoid the negative impact of direct competition associated with high levels of absolute conformity and possibly achieve competitive advantage.

The model offered here has managerial implications for hotel practitioners. One, it can help founders to understand the particularities of founding patterns by showing how zones in a city can serve as a guideline for predicting the behavior of future entries and perhaps as a basis for actions to deter them. Two, the model capturing the regularities in founding behavior is contestable. Sector models are always contestable, but their sociocognitive stickiness exacts a price. This might explain why innovations are rarely engineered by market insiders (Abrahamson and Fombrun 1994). The High Tech chain, which in the short span of four years has attained in Madrid the third largest number of hotels of any chain, serves as an example. Its success can be attributed to its strategy of entering the market, as its managers say, with a "distinct model" by renting emblematic and historic buildings in the old part of the city and by offering a renovated and modern service supply (Crowe 2004).

Several limitations of this study should be kept in mind when interpreting the results. First, this research uses prices as reported in an official guide. However, room pricing is considerably more complex because of different regimens, discounts, and supplements based on various criteria and because of seasonality of demand. It should be noted, however, that the possible bias incurred by this research is reduced, as this study does not deal with absolute price levels but with price differences. Second, price distance is a raw difference that does not control for the social valuation of money. This limitation could be corrected by separately estimating the behaviors of economy and upscale hotels. According to the results of Chun and Kalnins (2004), one would expect a negative relationship between geographic and price distances for economy hotels but not for upscale hotels. Finally, the conclusions about costs and benefits of agglomeration and differentiation strategies are predictions deduced from observed behaviors, as this paper has no measure of the explicit impact of positioning at founding on performance, an issue for future research. A 


\section{REFERENCES}

Åberg, Y.

1973 Regional Productivity Differences in Swedish Manufacturing. Regional and Urban Economics 3:131-156.

Abrahamson, E., and C. Fombrun

1994 Macrocultures: Determinants and Consequences. Academy of Management Review 19:728-755.

Aldrich, $\mathrm{H}$.

1979 Organizations and Environment. Englewood Cliffs: Prentice-Hall.

Arbel, A., and A. Pizam

1977 Some Determinants of Urban Hotel Location: The Tourists' Inclinations. Journal of Travel Research 15(3):18-22.

Ashforth, B., and B. Gibbs

1990 The Double Edge of Organizational Legitimation. Organization Science 1:177-194.

Ashworth, G.

1989a Urban Tourism: An Imbalance in Attention. In Progress in Tourism,

Recreation and Hospitality Management, C. Cooper, ed., pp. 33-54. London: Belhaven.

1989b Accommodation and the Historic City. Built Environment 15(2):92-100.

Ashworth, G., and J. Tunbridge

1990 The Tourist-Historic City. Chichester: Wiley.

Ayuntamiento de Madrid

1929 Información sobre la Ciudad. Memoria, Madrid, Imprenta, y Litografía Municipal. Ayuntamiento de Madrid.

Barney, J.

1991 Firm Resources and Sustained Competitive Advantage. Journal of Management 17:99-120.

Barney, J., and R. Hoskisson

1990 Strategic Groups Untested Assertions and Research and Research Proposals. Managerial and Decisions Economics 11:187-198.

Baum, J., and H. Haveman

1997 Love Thy Neighbor? Differentiation and Agglomeration in the Manhat-

tan Hotel Industry, 1898-1990. Administrative Science Quarterly 42:304-338.

Baum, J., and S. Mezias

1992 Localized Competition and Organizational Failure in the Manhattan

Hotel Industry, 1898-1990. Administrative Science Quarterly 37:580-604.

Bégin, S.

2000 The Geography of a Tourism Business: Hotel Distribution and Urban Development in Xiamen, China. Tourism Geographies 2:448-471.

Belsley, D., E. Kuh, and R. Welsch

1980 Regression Diagnostics: Identifying Influential Data and Sources of Collinearity. New York: Wiley.

Broadway, $\mathrm{M}$.

1993 Montreal's Changing Tourist Landscape. Canadian Journal of Urban Research 2:30-48.

Burtenshaw, D., M. Bateman, and G. Ashworth 1981 The City in West Europe. Chichester: Wiley.

Chun, W., and A. Kalnins

2001 Agglomeration Effects and Performance: A Test of the Texas Lodging Industry. Strategic Management Journal 22:969-988.

2004 Resource-Seeking Agglomeration: A Study of Market Entry in the Lodging Industry. Strategic Management Journal 25:689-699.

Ciccone, A., and R. Hall

1996 Productivity and the Density of Economic Activity. The American Economic Review 86(1):54-70.

Crowe, D.

2004 Hoteleros de Nueva Estirpe. El País Negocios 984:7. 
de Bres, K.

1994 Cowtowns or Cathedral Precincts? Two Models for Contemporary Urban Tourism. Area 26:57-67.

Deephouse, D.

1999 To Be Different, or to be the Same? It's a Question a Theory of Strategic Balance. Strategic Management Journal 20:147-166.

DiMaggio, P., and W. Powell

1983 The Iron Cage Revisited: Institutional Isomorphism and Collective Rationality in Organizational Fields. American Sociological Review 48:147-160.

Egan, D., and K. Nield

2000 Towards a Theory of Intraurban Hotel Location. Urban Studies 37:611-621.

Ellinger, R.

1977 Industrial Location Behavior and Spatial Evolution. The Journal of Industrial Economics 25:295-312.

Fischer, J., and J. Harrington

1996 Product Variety and Firm Agglomeration. RAND Journal of Economics 27:281-309.

Fujita, M., and J. Thisse

1996 Economics of Agglomeration. Journal of the Japanese and International Economies 10:339-378.

Gavira-Martin, J., and C. Gavira-Golpe

1999 Madrid, Centro y Periferia. Madrid: Biblioteca Nueva.

Gimeno, J., and C. Woo

1996 Hypercompetition in a Multimarket Environment: The Role of Strategic

Similarity and Multimarket Contact in Competitive Deescalation. Organization Science 7:322-341.

Gordon, I., and P. McCann

2000 Industrial Clusters: Complexes, Agglomeration and/or Social Networks? Urban Studies 37:513-532.

Graitson, D.

1982 Spatial Competition a la Hotelling: A Selective Survey. The Journal of Industrial Economics 31:13-25.

Gripsrud, G., and K. Gronhaug

1985 Structure and Strategy in Grocery Retailing. A Sociometric Approach. The Journal of Industrial Economics 33:339-347.

Guimaraes, P., O. Figuereido, and D. Woodward

2000 Agglomeration and the Location of Foreign Direct Investment in

Portugal. Journal of Urban Economics 47:115-135.

Gutiérrez, R.

1977 Localización Actual de la Hostelería Madrileña. Boletín de la Real Sociedad Geográfica 2:347-357.

Hatten, K., and M. Hatten

1987 Strategic Groups, Asymmetrical Mobility Barriers and Contestability.

Strategic Management Journal 8:329-342.

Hausman, J.

1978 Specification Tests in Econometrics. Econometrica 46:1251-1271.

Henderson, J.

1986 Efficiency of Resource Usage and City Size. Journal of Urban Economics 19:47-70.

2003 Marshall's Scale Economies. Journal of Urban Economics 53:1-28.

Henderson, J., Z. Shalizi, and A. Venables

2001 Geography and Development. Journal of Economic Geography 1:81-105.

Hotelling, $\mathrm{H}$.

1929 Stability in Competition. Economic Journal 39:41-57.

Ivars, J.

2004 Tourism Planning in Spain: Evolution and Perspectives. Annals of Tourism Research 31:313-333. 
Johnson, K., and W. Clifton

1996 Budget Hotels. In Introduction to Hospitality Operations, P. Jones, ed., pp. 61-72. London: Cassell.

Koutsoyiannis, A.

1977 Theory of Econometrics (2nd ed.). New York: Macmillan.

Krugman, P.

1991 Geography and Trade. Leuven: Leuven University Press.

Marshall, A.

1925 Principles of Economics (8th ed.). London: Macmillan.

Meyer, J., and B. Rowan

1977 Institutionalized Organizations: Formal Structure as Myth and Ceremony. American Journal of Sociology 83:340-363.

McCann, P.

1995 Rethinking the Economics of Location and Agglomeration. Urban Studies 32:563-577.

Moomaw, R.

1981 Productivity and City Size: A Critique of the Evidence. Quarterly Journal of Economics 96:675-688.

1988 Agglomeration Economies: Localization or Urbanization? Urban Studies 25:150-161.

Nakamura, R.

1985 Agglomeration Economies in Urban Manufacturing Industries: A Case of Japanese Cities. Journal of Urban Economics 17:108-124.

Oppermann, M., K. Din, and S. Amri

1996 Urban Hotel Location and Evolution in a Developing Country. The Case of Kuala Lumpur Malaysia. Tourism Recreation Research 21(1):55-63.

Peteraf, M.

1993 The Cornerstones of Competitive Advantage: A Resource-Based View. Strategic Management Journal 14:179-191.

Pillen, P.

1995 Les Mutations Récentes dans le Paysage Hôtelier Bruxellois. Revue Belge de Géographie 119:357-368.

Porac, J., and H. Thomas

1994 Cognitive Categorization and Subjective Rivalry among Retailers in a Small City. Journal of Applied Psychology 79:54-66.

Porter, M.

1991 Towards a Dynamic Theory of Strategy. Strategic Management Journal 12:95-118.

Reger, R., and A. Huff

1993 Strategic Groups: A Cognitive Perspective. Strategic Management Journal 14:103-124.

Quigley, J.

1998 Urban Diversity and Economic Growth. Journal of Economic Perspectives 12(2):127-138.

Shoval, N., and K. Cohen-Hattab

2001 Urban Hotel Development Patterns in the Face of Political Shifts. Annals of Tourism Research 22:908-925.

Sveikauskas, L.

1975 The Productivity of Cities. Quarterly Journal of Economics 89:393-413.

Tabuchi, T.

1986 Urban Agglomeration Economies, Capital Augmenting Technology, and Labor Market Equilibrium. Journal of Urban Economics 20:211-228.

Tickell, A.

2002 Geography of Services: Progress in the Geography of Services III-Time to Move on? Progress in Human Geography 26:791-801.

Timothy, D., and G. Wall

1995 Tourist Accommodation in an Asian Historic City. The Journal of Tourism Studies 6(2):63-73.

Wall, G., D. Dudycha, and J. Hutchinson

1985 Point Pattern Analyses of Accommodation in Toronto. Annals of Tourism Research 12:603-618. 
Weaver, D.

1993 Model of Urban Tourism for Small Caribbean Islands. Geographical Review 83:134-140.

Weber, A.

1909/1929 Theory of the Location of Industries. Chicago: Univerisity of Chicago.

Yokeno, N.

1968 La Localisation de l'Industrie Touristique: Aplication de l'Analyse de Thunen-Weber. Cahiers du Turisme (vol. C-9). Aixen-Provence: CHET. Zellner, A., and $\mathrm{H}$. Theil

1962 Three-Stage Least Squares. Simultaneous Estimation of Simultaneous Equations. Econometrica 30:53-68.

Submitted 25 June 2003. Resubmitted 23 December 2004. Resubmitted 29 April 2005. Final version 21 June 2005. Accepted 21 August 2005. Refereed anonymously. Coordinating Editor: David A. Dittman

Available online at www.sciencedirect.com

SCIENCE d DiRECT ${ }^{\circledR}$ 